Folia primatol. 1983;40:I-IV

\title{
Contents, Vol. 40, 1983
}

S. Karger $\square$ Medical and Scientific Publishers $\square$ Basel $\cdot$ München $\square$ Paris $\cdot$ London · New York - Tokyo - Sydney

All rights reserved.

No part of this publication may be translated into other languages, reproduced or utilized in any form or by any means, electronic or mechanical, including photocopying, recording, microcopying, or by any information storage and retrieval system, without permission in writing from the publisher or, in the case of photocopying, direct payment of a specified fee to the Copyright Clearance Center (see 'Information for Readers and Subscribers').

Copyright 1983 by S. Karger AG, P.O. Box,

CH-4009 Basel (Switzerland) Printed in Switzerland by Thür AG Offsetdruck, Pratteln Index Vol. 40,1983

No. 1-2 Front Dentition of the Omomyiformes (Primates)

Schmid, P

Scapula oïApidium phiomense: A Small Anthropoid from the Oligocene of Egypt

Anapol, F 11

Size and Diet in the Evolution of African Ape Craniodental Form

Shea, B.T

32

Premaxillary-Maxillary Suture Asymmetry in a Juvenile Gorilla. Implications for Under standing Dentofacial Growth and Development

Schwartz, J.H 69

Taxonomy and Phylogeny of Black-and-White Colobus Monkeys. Inferences from an Anal ysis of Loud Call Variation

Oates, J.F.; Trocco, T.F

Structural Variability in Primate Vocalizations and Its Functional Significance: An Analysis of Squirrel Monkey Chuck Calls

Newman, J.D.; Smith, H.J.; Talmage-Riggs, G 114

Females Without Infants: Mating Strategies in Two Species of Captive Macaques

Small, M.F 125

Use of the Forest Canopy by the Agile Gibbon

Gittins, S.P 134

Inter-Troop Transfer of Lemur catta Males at Berenty, Madagascar

Jones, K.C 145

No. 3 Comportement vocal des males adultes et organisation supraspécifique dans les troupes polyspécifiques de cercopithèques (Vocal Behaviour of Adult Males and Superspecific 
Organization in Polyspecific Troops of Monkeys)

Gautier, J.-P.; Gautier-Hion, A

161

Introduction and Dominance Manipulations Involving Old Rhesus Males

Williams, L.E.; Bernstein, I.S 175

Langur Monkey Mother Loss: Profile Analysis with Multivariate Analysis of Variance for

Separation Subjects and Controls

Dolhinow, P.; Murphy, G 181

Polymorphisme électrophorétique chez Erythrocebus patas (Electrophoretic Polymorphism

in Erythrocebus patas)

Lucotte, G.; Dandieu, S

The Bp Graded Blood Group System of the Baboon: Its Relationship with Macaque Red Cell Antigens

Socha, W.W.; Moor-Jankowski, J.; Ruffié, J 205

Karyotype of Saguinus labiatus labiatus (Red-Bellied Marmosets)

Marczynska, B.; Peterson, D.A.; Ogden, J.D.; Wolfe, L.G 217

The Karyotype of Galago crassicaudatus Is Ancestral for Lorisforms

Rumpler, Y.; Couturier, J.; Waiter, S.; Dutrillaux, B 227

Book Review 232

IV Index

No. 4 Effects of Reproductive State on Vocalizations in Squirrel Monkeys (Saimiri sciureus)

Smith, H.J.; Newman, J.D.; Bernhards, D.E.; Symmes, D 233

Food Aversion Learning in Japanese Monkeys (Macaca fuscata). A Strategy to Avoid a

Noxious Food

Matsuzawa, T.; Hasegawa, Y 247

Learning Set Formation in Slow Lorises (Nycticebus coucang)

Ohta, $\mathrm{H} \quad 256$

Relationship between Social Interactions and Sexual Maturation in Female Saguinus oedipus oedipus

Tardif, S.D 268

Lactation and Fertility: An Examination of Nursing and Interbirth Intervals in Cotton-Top

Tamarins (Saguinus o. oedipus)

French, J.A 276

Eine Rekonstruktion des Skelettes von A.L. 288-1 (Hadar) und deren Konsequenzen

(A Reconstruction of the Skeleton of A.L. 288-1 (Hadar) and Its Consequences)

Schmid, P 283

Author Index 307 